AÜIFD Cilt XLIII (2002) Sayı 2 s.391-403

\title{
Kelime Çeşidi Olan Harfin Tanımına ve Özelliklerine Eleştirel Bir Yaklaşım
}

\author{
M. Edip ÇĂ̆MAR \\ Arş. Görr., Dicle Üniversitesi İlâhiyat Fakültesi
}

A critical approach to the meainng ana charecteristics of letter which is type of word. This study has dealt with definition and characteristic of letters in Arabic language; however in this article has been analyzed their definition and characteristic. Before all else the senses of letter word in Arabic dictionaries is given in order to be understood the subject pretty good. Separately definitions which are famous in Arabic gramer is mentioned. At the same time the explanation and criticism about contents of this definitions together our opinion is given. According to us the best definition have been expressed. Besides we touched on the characteristic of names and verbs to be under stood the definition of the letters. The second part of this article is connected with characteristic of letters. Particularly knowledge on spiritual and utterance propertry of letters is given.

Key Words: Arabic, letter, definition, definition and charateristic, utterance, spiritual

\section{Giriş}

Bilindiği üzere Arap Dili Grameri'nde kelimeler üç kısma ayrılmaktadır. Bunlar isim, fiil ve harftir. Gramer kitaplarında bunlar için 
değişik tanımlar yapılmış ve değişik özelliklerden bahsedilmiştir; ancak tespit edebildiğimiz kadarıyla kelime çeşitlerinden biri olan harf için yapılmış tanımların çoğu ya eksik ya da müphemdir. Harfin özelliklerine gelince, gramer kitaplannda genelde lafzî yönüyle ilgili özellikler zikredilmiş; manevî özelliklerine ise fazla değinilmemiştir.

Bu makaleyi yazmamızın sebebi, harf için yapılmış tanımları değerlendirmek, o tanımlara yöneltilmiş olan eleştirileri ortaya koymak ve harf için uygun olan tanımı belirlemeye çalışmaktır. Diğer bir sebep ise, harfin hem lafız hem de mana ile ilgili özelliklerini izah etmektir.

Arap dilinde harf, bir gramer konusu olduğundan dolayı, nahivcilerin görüşlerini dikkate alarak ve değerlendirerek konuyu incelemeye çalıştık; bu nedenle harfin tanımları için sistematik bir tasnif ya da gruplandırma yapmadık. Onun yerine önce harfle ilgili önemli bir kısım tanımlan zikrettik; daha sonra onları açıklayıp değerlendirmeye çalıştık.

\section{Harfin Tanımı}

Harf kelime olarak, herhangi bir şeyin kenarı, tarafı, sının, suyun aktığı yer, yolculuktan olayı zayıf ve yorgun düşmüş deve anlamlarına gelmektedir.' Arap dilinde bu anlamlarla ilgili çok örnek görülür. Mesela,

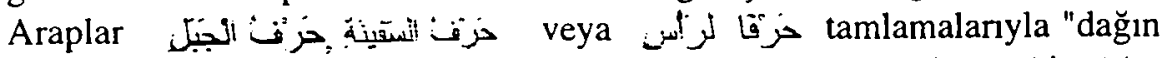
حر"ف "أنساء ${ }^{2}$ tamlaması ise, "suyun aktığı yer"i ifade eder. Harf kelimesi, عن ile beraber

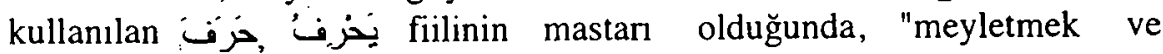
sapmak" anlamlarında kullanılır. Söz konusu fiil mecrûr isimden başka herhangi bir isim alıyorsa, bu durumda harf kelimesi "çevirmek ve değiştirmek" manalanna gelir; fakat harf kelimesi, J cer harfi

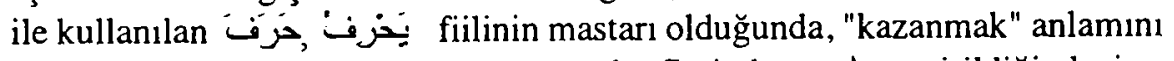
ifade eder. Bu kelimenin başına cer harflerinden على getirildiğinde ise, "şüphelenme, mutmain olmama ve bir şeyin kenarında bulunma" manalarını ifade eder. ${ }^{3}$ İbn Fâris (395/1004), harf kelimesinin hem bir şeyin yüzü hem de bir şeyi değerlendirmek anlamına geldiğini söylemektedir. ${ }^{4}$

1. İsmail b. Hammad el-Cevherî, es-Sihah fil-luğa,"h-r-f" md., Thk. Ahmed Abdulgaffur Attar, Daru’-İlim lìl-Melâyîn Beyrut, 1990, IV, 1342; Cemaluddin Muhammed b. Mukerrem b. Manzûr, Lisanu'l-Arab, "h-r-f" md., Thk.Muhammed Sadık el-Ubeydî ve Emin Abdulvahhab, Daru İhyai t-Turasi l-Arabi, Beyrut, 1996, III, 129;, Muhibbuddin Ebû Feyd es-Seyyid ez-Zebîdî, Tacu'l-Arûs min Cevahiri'l-Kamûs, "h-r-f" md., Beyrut, Daru'l-Fikr,tsz, VI, 67.

2. el-Cevhen̂, a.g.e, "h-r-f" md., IV,1340; İbn Manzûr, a.g.e, "h-r-f" III, 129; ez-Zebîdî, a.g.e, "h-r-f" md.,VI, 6

3. Heyetu'l-Mecme' i'l-Lugati'l-Arabi, el-Mu'cemu'l-vasît, "h-r-f" md., Çağrı Yayınları, İstanbul, 1986, I. 16

4. Ahmed b. Fâris, Mu'cemu'l-mekâyîsi l-luğa,"h-r-f" Daru’l-Ciyl, Beyrut tsz., II, 42. 
Harf kelimesi, yukarıda zikrettiğimiz anlamlann dışında lügat, vecih, lehçe, yol, kelime ve hece harfleri için de kullanılır. ${ }^{5}$ Bu kelime, suyun aktığı yer veya bir şeyin kenan anlamında kullanılınca çoğulu yalnız أخرُفْ olma durumları dışında ise, çoğulu حُرُونَ veya أخرُف âlimleri, bir kelime çeşidi olan harfin ıstılâhî anlamı için değişik tanımlar yapmışlardır. Yapılan tanımlardan bazıları şunlardır:

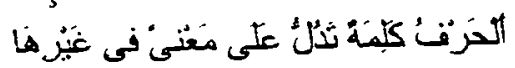

"Harf, kendinden başka bir lafızda bulunan manaya delâlet eden bir kelimedir."7 Bu, yaygın olan bir tanımdır:

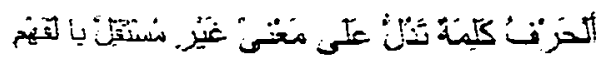

"Harf, anlamı bağımsız anlaşılmayan bir kelimedir."8

Bazıları ise, harf için aşağıdaki ifadelere benzer bir tanım yapmışlardır:

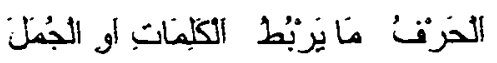

"Harf, cümle veya kelimeleri birbirlerine bağlayandır." 9

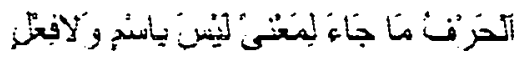

"Harf, ne isim ne de fiil olan bir mana için kullanılan kelimedir." 10

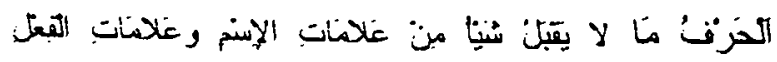

"Harf, isim ve fiilin özelliklerinden hiçbirini taşımayan kelimedir."1ı

Harf için aynca şu tanımlar da yapılmıştır: "Harf, cümlede ne müsnedün bih ne de müsnedün ileyh olarak kullanılabilen bir kelimedir."12

5. el-Cevher̂, a.g.e, "h-r-f" md., IV,1340; İon Manzûr, a.g.e, "h-r-f" md., III, 129; Mecduddin Muhammed b. Ya'kub el-Fîrûzâbâdî, el-Kâmûsu'l-muhit, "h-r-f" md., Daru'lCiyl, Beyrut, tsz, III, 130; cz-Zebîdî, a.g.e, "h-r-f" md., VI.

6. İbn Manzûr, a.g.e, "h-r-f" md., III, 132.

7. Mahmud b. Ömer ez-Zemahşeri, el-Mufassal fi ilmi l-luga, Daru Ihyai l-Ulum, Beyrut 1410/1990, s. 337; Osman b. Ömer İbnu`l-Hacib, el-Kâfiye, (el-Mutûnu’l-kamile ile birlikte basılmış.) Daru' l-Fikr, Beyrut 1418/1997, s. 225; Celâleddin es-Suyûtî, Hemu'lhevami', Thk. es-Seyyid Muhammed Bedruddin en-Nasanî, Menşurat er-Radi z-Zahidi, Kum,1985, I,4.

8. Mehmed Birgivî, İhâru'l-esrâr, (Mutûnu'l-kâmile ile birlikte basılmış), Daru'l-Fikr 1418/1998, s. 251; Mustafa b. Hamza, Netâicu'l-efkâr, yaysz., ysz., tsz., s. 28.

9. Krş. Ibn Manzûr, a g.e. "h-r-f" md., III, 132; cz-Zebîdî, a. g.e., "h-r-f" md., XII, 123.

10. Sibeveyhû, el-Kitâb, Daru' l-Ciyl, Beyrut tsz., I, 12; el-Hasan b. Ahmed Ebû Ali el-Fârisî, Kitabu'l-îdâh, Thk. Kazım Bahr el-Murcân, Alemu`l-Kutub, Beyrut 1416/1996, s. 72.

11. Cemaluddin b. Yusuf b. Hişam el-Ensari, Şerhu 'l-Katır, Thk. Muhammed Muhyiddin Abdulhamîd, Mektebetu' l-Fîrzâbâdî, Kum, 1994, s. 6; Nuruddin el-Eşmûnî, Şerhu'lEşmûnî, Darül-Fikr, ysz., tsz.I, 1. cüz, 43.

12. Krş. Muhammed b. Serrâc, el-Usûl fi n-nahiv, Muessesetiu’ r-Risale, Beyrut 1417/1996, I, 40; Abdullah b. Hüseyin el-Ukbeñ, el-Lubâb fi 'ileli l-bina ve'l-ìrâb, Daru'l-Fikr, Dımaşk 1416/1995, I, s. 51 . 
"Harf, cümledeki kullanımına göre, anlamı olan kelimedir."13

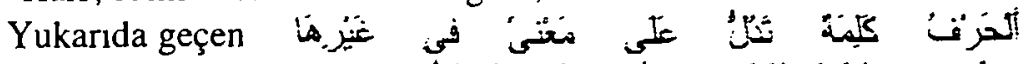
ve yapılmış veya yapılabilecek eleştirilere, bazı âlimler cevap vermeye çalışmışlardır. Bu eleştirilerden birincisi; 'ن إلىى ني vb. kelimelerin harf olarak, onların manalarını ifade eden ibtida (başlama), intiha (son bulma) kelimelerinin ise isim olarak kabul edilmelerine yöneliktir. Bu eleştiriye göre w ve ibtida kelimesi aynı özelliğe sahip olmalarından dolayı, bunların aynı kelime çeşidinden olmalan gerekir. Bu nedenle birinin harf; diğerinin isim olarak kabul edilmesinin yanlı̧̧ olduğu ifade edilmiştir. Molla Câmî (898/1432) bu eleştiriye, نs ile ibtida kelimesi arasındaki mana farkını açıklayarak şöyle cevap vermektedir: "Burada; ibtidadan kastedilen küllî bir anlamdır ve bu anlam başka bir manadan dolayı da kastedilmemektedir. $ن$ 'in manası ise, o küllün cüzünden bir manadır ve bu cüz söz konusu fiil ile fiilin başladığı yer arasındaki başlama ilişkisidir. من نbu

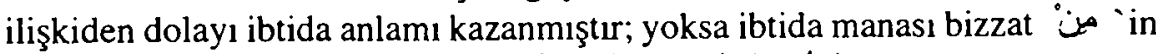

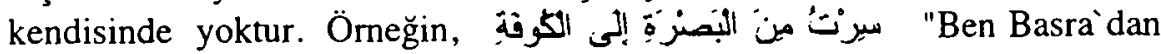
Kufe ye gittim." cümlesinde, Basra ile gitme fiili arasında bir ilişki vardır. $\mathrm{O}$ da "gitme fiilinin Basra’ dan başlamış olması"dır. İşte bu cümledeki başlama vasfı, genel anlamdaki başlamak mefhumunun bir parçasıdır ve من Basra ile gitme fiili arasındaki başlama ilişkisinden dolayı kullanılmıştır."14 Muhammed Ali et-Tehânevî (1157/1744) de "Keşşafu ıstılahati l-funûn" adlı eserinde, aynı açıklamalarda bulunmuştur. ${ }^{15}$

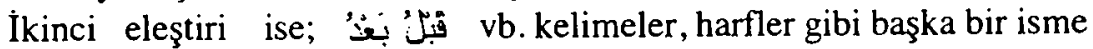
ihtiyaç duydukları hâlde, harf olarak kabul edilmemelerine yöneliktir; çünkü "harf başkasında bulunan manaya delâlet eder" tanımına göre, bunlar da harf olmaktadır. Bundan dolayı bunlara da harf demek gerekir. Buna da bazı

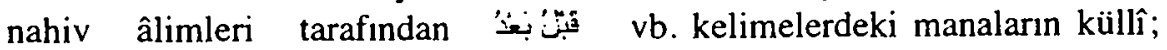
harflerdeki manaların ise cüzî olduğu şeklinde cevap verilmiştir ki , bu cevap yukarıdaki eleştiriye verilen cevabın aynısıdır. ${ }^{16}$

Üçüncü eleştiri ise, yukarıdaki tanımda geçen delâletten maksat, şumûlî ${ }^{17}$ bir delâlet ise, fiilin de bu tanımın kapsamına girmesi gerekir; zira

13. Said Isbir-Bilal Cüneydi, eş-Samil mu'cemun fi 'ulûmi l-luğati l-Arabiyye ve mustalahâtihâ. Daru' l-'Avde, Beyrut 1985, s. 449,872.

14. Abdurrahman b. Ahmed Molla Câmî, el-Fevâidu'd-diyâiyye, s.12.

15. bkz. Muhammed Ali et-Tehânevî, Keşsâfu ıstllâhati l-funûn, "i-s-m" md., I, 712.

16. Molla Câmî, a.g.e., s. 13.

17. Lafız, anlamının bütününe delâlet ediyorsa, delâlet şumûlî; bir kısmına delâlet ediyorsa, delâlet tazammunî olur. Ömeł̧in, insan lafzının, insanın bütüüne delâlet etmesi, şumûlî; canlı olmasına delâlet etmesi ise, tazammunîdır. (el-Mağnisâvî, Muğni t-tullâb, s. 14). 
fiil, fâile ve bazen de mefulün bihe ihtiyacı olan bir nisbeti gerektirmektedir. Bu nisbet olmadan insan zihninde ve dış dünyada fiil, meydana gelemez. Bu eleştiriye de fiilin tanımındaki delâletten maksadın, tazammunî delâlet olduğu ifade edilerek cevap verilmiştir. ${ }^{18}$ Yani fiilde hades (oluş), nisbet ve zaman mefhumları vardır; 19 Verilen cevaba göre, herhangi bir kelimeye fiil denmesinin nedeni, o kelimenin sadece hades yönüdür.

Bize göre, -her ne kadar bazı âlimler yukanda verdiğimiz tanımlara yöneltilen bazı eleştirilere karşı cevap vermişlerse de-söz konusu tanımlar, efradını câmi ve ağyarını mani bir vasfa sahip değildir ve onlarda kapalılık vardır. Bilindiği gibi tariflerde, efradı câmi ve ağyarı mani özelliğinin bulunması şarttır. ${ }^{20}$ Işte bu bağlamda yukarıda geçen

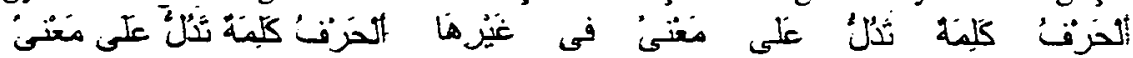

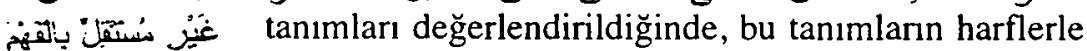
beraber, isimleri ve fiilleri de kapsadığı görülecektir. Bazı âlimlerin bu tanımları yanlış kabul etmelerinin sebebi bu olabilir.

Konunun daha iyi anlaşılması için, yukarıda zikrettiğimiz eleştirilere verilen cevapları biraz daha açıp tartı̧̧mak istiyoruz; zira onlar, söz konusu eleştiriler için tam bir cevap olmamıştır. Örneğin, ibtida, intiha vb. isimlerin manaları küllî, المى، vb. harflerin manaları ise cüzîdir demek, pratikte hiçbir anlam ifade etmez; zira hem ibtida, intiha vb. kelimeler hem de إلى, vb. edatlar kullanımda başka bir isme ihtiyaç duymaktadır. İbtida, intiha vb. kelimelerin, kendilerinden sonra isim bulunmadığ durumlarda pratikte vb. edatlarla aynı olmadıklanı iddia edilse de, bu iddia yanlış olur; çünkü bazen harflerden sonra gelen fiil veya isim de hazfedilebilir. ${ }^{21}$ vb. harflerin manaları küllî; ancak değişik cümlelerdeki kullanımlan ise cüzî olduğu söylenebilir; yani من'in manası ibtidau'l-ğaye (başlangı̧ noktası)dır. من denince, insanın aklına bu anlam gelmekte; ancak cümlede kullanıldığında ise, Basra, Kûfe veya başka herhangi bir yerin başlangıç noktası söz konusu olabilmektedir. Bu durumda ibtida, intiha vb. kelimelerle, اللى، من vb. edatlar arasında hiçbir fark kalmamaktadır.

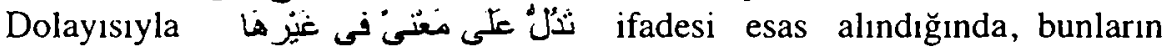
hepsinin aynı kelime çeşidi altında toplanması gerekmektedir.

18. Mehmed Birgivî, Imtihanu'l-ezkiyâ, Sahâfiye-i Osmaniyye Matbaası, İstanbul tsz., s. 11.

19. ed-Dakr, Mu'cemu'l-kava'idi'l-Arabiyye, Daru'l-Kalem, Dımaşk 1414/1993, s. 351; Ahmed Taib Osmanzade, Kurâdetï z-zeheb fi ilmeyi'n-nahvi ve l-edeb, Thk. Muhammed Altunci, Daru Sadır, Beyrut 1998, s.172; Bu konu hakkında geniş bilgi için bkz nahiv kitaplarındaki fiil tanımlarına.

20. Celâleddin el-Mahallî, Cem 'u'l-cevâmi', Diyarbakır. I, 132.

21. Ibn Hişam, Evdahu'l-mesalik. Thk. M. Muhyiddin A. Hamid, Matbaatủ Emîr, Kum 1387/1967, I. IV, 202. 
Bazı nahiv âlimlerinin قَبَّن بُخْ vb. kelimelerden dolayı harfin tanımına yönelik eleştirilere yaptıklan itiraz için de, biraz önce ibtida, intiha ve konusunda ifade ettiklerimizin aynısı söz konusu edilebilir. Ayrıca

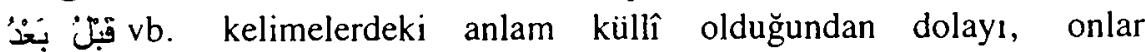
kendilerinden başkasında bulunan manalara delâlet etmez şeklinde bir söz, ancak vâzi (dil koyucu)in bu tür kelimeleri soyut olarak düşünmesi durumunda geçerli olur; çünkü insan zihni sürekli bu tür manaları başka şeylere nisbet ederek düşünür ve bunun için de bunlan ifade eden isimler sürekli başka bir isimle beraber olur. Onlarla beraber başka isim lafzen zikredilmezse bile, insan zihni sürekli onları başka isimlere izafe ederek düşünür. Buna göre, بعذ gibi kelimeler, genelde insanların zihinlerindeki konuma göre harf; soyut anlamlarıyla da isimdir denebilir.

Fiildeki delâlet, tazammunî olduğundan dolayı, nisbette fiilin, fâil veya mefûle ihtiyaç duyması durumu, fiili, harfin tanımının kapsamına sokmadığını söylemek doğru olmayabilir; çünkü böyle bir itirazı yapan kimsenin yanında da, fiil müstakil hades ve müstakil olmayan nisbete delâlet etmektedir. Sonuçta buna göre, fiilin delâleti, şumûlî olmaktadır. Delâletinin şumûlî olması, onun da harf gibi bir isme ihtiyaç duyduğu ve harfin tanımının kapsamında olduğu anlamına gelmektedir. Fiil sadece hadese delâlet eder görüşü kabul edildiğinde ise, anlamı tazammunî olur; fakat bunun doğruluğunu kabul etmek zordur; zira burada tazammunî delâletle söz konusu olan kelime, nispet ve zamanı kapsamadığından fiil değil de; ancak mastar olabilir. Sebebi ise, sadece hadese delalet etmek olayı, mastar için geçerli olmasıdır. ${ }^{22}$ Yani tazammunî delâlet, fiili hadesle sınırlandırmaktadır. Halbuki fiil, hades, nisbet ve zaman mefhumlarından oluşmaktadır. Aynca tazammunî delâlet kabul edilse bile, fiil, hades dışındaki şeylere delâlet etmekten kurtulamaz; zira her fiilin belli bir zamana ve nisbete delâlet etmesi şarttır. İşte buna göre, fiil de harf gibi, başkasında bulunan bir manayı ifade etmiş olmaktadır. Fiilin tanımındaki delâletin tazammunî olduğunu ifade eden Mehmed Birgivî (981/1573) bile, tazammunî delâleti gerektiren karinede bir kapalılığın bulunduğunu söylemektedir. ${ }^{23}$ Bütün bunların dışında, tanımın bu şekilde sınırlandırılması, tanımın başka bir söze ihtiyaç duymaması ilkesine ters düşmektedir; zira bu tanımın tanımlanmasını gerektirmektedir. ${ }^{24} \mathrm{Bu}$ durumda tanımlanan tanımın hiçbir anlamı kalmamaktadır.

22. Ibn Hişam, Şerhu'ş-suzûri'z-zeheb, s. 502; el-Galâyînî, Câmi'u'd-durusi'l-arabiyye, I, 160

23. Mehmed Birgivî, Imtihânu'l-ezkiyâ, s. 11.

24. İbrahim Emiroğlu, Ana Hatlarıla Klâsik Mantlk, Asa Kitabevi, İstanbul 1999, s. 100. 
Diğer tanımlara gelince, onlanı tanım olarak kabul etmeyen âlimler vardır. Bu âlimlere göre, bunlar tanım şartlarını hâiz olmayıp harfin özelliklerini belirten ifadelerdir.25 Bize göre, birçok nahiv âliminin

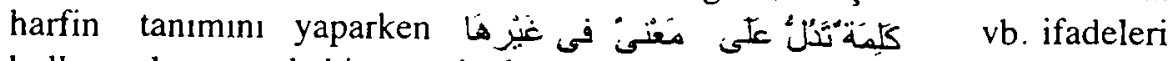
kullanmalarının sebebi, mantıkçıların tanımlarda cins ve faslın şart olduğunu ileri sürmelerinden ${ }^{26}$ kaynaklanmaktadır; her ne kadar mantıkçıların

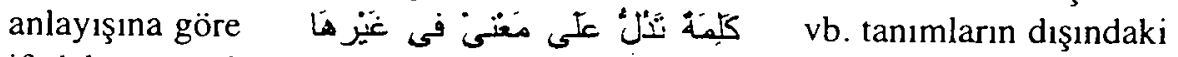
ifadeler tanım kapsamına girmese bile, biz, bunları tanım olarak kabul etmeyi uygun görüyoruz; zira bazen bu tür ifadelerdeki bir özellik bile, tanımlanan şeyin nasıl bilineceğini kolay bir şekilde gözler önüne sermektedir.

şeklindeki tanımın da harfler için, efradını câmi, ağyarını mani olmadığını görmekteyiz; çünkü bütün harfler kullanıldıklan cümlelerde, kelime veya cümleleri birbirine bağlama görevini üstlenmemektedir. Örneğin, zâid harfler geldikleri cümlelerde rabt (bağlama) görevini yapmadıkları halde,27 harf olarak kabul edilmişlerdir. Bu noktadan bakıldığında, bu tanımın zâid harfleri kapsamadığı ortaya çıkmaktadır. Halbuki bu tanım, harfleri kapsayan bir tanım olsaydı, zâid harflere de şâmil olması gerekirdi.

Ayrıca bu tanıma göre, cümlede bağlaç görevini gören isim veya fiil olan bazı edatlar ${ }^{28}$ da harfin kapsamına girmektedir. Harf, cümledeki yerine göre, anlamı olan veya müsnedün ileyh ve müsnedün bih olmayan kelime olduğu şeklindeki ifadeler ise harfin tek bir özelliğine işaret etmektedir.

tanımı ise doğru olsa bile, onda müphemlik vardır; zira harfin manası bu tanımda geçtiği şekliyle, isim ve fiilin manası değildir; ancak burada bir mananın harf olup olmadığını tespit etmeye yardımcı olan hiçbir şey yoktur.

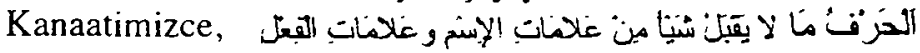
şeklindeki tanım harf için en doğru tanımdır. İsim ve fiilin özelliklerini kabul etmeyen kelimeler, isim ve fiilin dışında bir kelime çeşidi olduklanı intibaı uyandırır. Bunların dışındaki kelime çeşidi yalnız harf olduğuna göre, bunlann özelliklerini kabul etmeyenler harftir.

25. Ebu'l-Kasım ez-Zeccâcî, el-îdâh fỉ ileli n-nahiv. Thk. Mazın Mübarek, Daru’n-Nefâis, Beyrut 1406/1986, s. 55; Hasan b. Kasım el-Murâdî, el-Cene'd-dânî fî hurûfí l-meanî, Thk. Fahruddin Kabave-M. Nedim Fazıl, Daru'l-Kutubi' l-Imiyye, Beyrut 1413/1992 s. 24.

26. el-Mağnisâvî, Muğni t-tullab, Salah Bilici Kitabevi, Istanbul tsz., s. 33.

27. Muhammed b. Hasan er-Radiyy, Şerhu'r-Radiyy, Cami`a tü Karyunus, basım yeri belli değil I398/1978, IV, 432vd.

28. M. Said İsbir-Bilal Cüneydî, eş-\$âmil, "e-d-t" md., s. 66. 
Zikrettiğimiz bu tanımın harf için uygun tanım olmasının diğer nedenlerini şu şekilde sıralayabiliriz;

1-Bazı âlimlerin zikrettiğimiz tanımların harfe tanım olmayacaklarını söylemeleri. Örneğin, el-Fînûzâbadî "el-Kâmûsu'l-muhît" adhı eserinde, söz konusu tanımların harfi ifade etmediğini söylemektedir. ${ }^{29}$

2- Bütün nahiv âlimlerinin, harf olarak kabul edilmiş kelimelerin başına isim alametleri geldiğinde, onların isimleştiğine dair ittifak etmeleri. ن

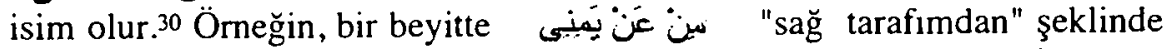
geçen ifadedeki نَ harfinin isim olduğu belirtilmiştir. Nedeni ise من ين ئن harfi cerrin نَ in başına gelmiş olmasıdır.

3- İsim ve fiil için zikredilen alametler, genelde açık lafzî işaretlerdir. $\mathrm{Bu}$ ise kelimenin bilinmesini kolaylaştırmaktadır. Bu durumda içinde isim ve fiil olduğuna dair bir alameti taşımayan lafizlar harf olur.

4- Bu tanımlan tanım olarak kabul etmemizin diğer bir nedeni ise, mana yönünden harflere benzeyen isim ve fiilleri harflerin dışında tutmasıdır; çünkü isim ve fiil olan edatlar mana açısından harfler gibi cümle ve kelimeleri birbirlerine bağlamaktadır ${ }^{32}$ Buna göre, bu tür edatların da harf olması gerekmektedir. İşte harfleri, bu tür edatlardan ayıran en önemli özellik, isim veya fiil alametlerini taşımamalarıdır. Bunun için ne kadar edatlar harfe benziyorlarsa da, harften sayılmamışlardır.

Bundan anlaşıldığına göre, bir şeyin harf olup olmadığını tespit etmek için isim ve fiilin özelliklerini de bilmek gerekir. İsmin özellikleri; ì râb alması, başına ll takısı gelmesi, tenvin alması ve müsnedün ileyh olmasıdır. Fiillerin özellikleri ise, sonlarına merfû mutaharrik zamirlerin ve te’nîs ت

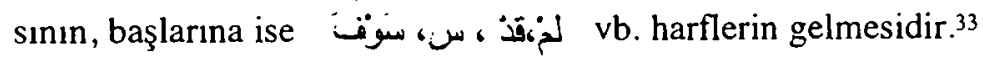

\section{Harflerin Özellikleri}

Nahiv âlimleri, kelimenin her üç kısmı için de bazı özellikler zikretmişlerdir. Işte bu özelliklerle hangi kelimenin harf olduğu; hangisinin

29. el-Fîrûzâbâdî, el-Kâmûsu'l-muhît, «h-r-f» md., III, 131 .

30. Abbas Hasan, a.g.e, II $, 512,515,516$. Ayrıca bu konu hakkında geniş bilgi için bkz. nahiv kitaplarının ilgili bölümlerine.

31. Abdullah b. Akil, Şerhu Ibn Akîl 'alâ'l-Elfiyye. Thk. M. Muhyiddin A.Hamid, elMektebetü'l-Asriyye, Beyrut 1415/1995, II, 30; Muhammed el-Hudarí, HâşiyetülHudarî, Daru`l-Fikr, Beyrut 1409/1989, I, 232.

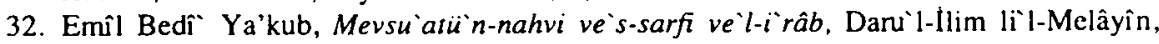
Beyrut 1998, "e-d-t" md., s. 32.

33. Ibn Akîl, a.g.e., I, 21 vd., 26vd.; Halid el-Ezherí, Şerhu't-Tasrîh 'alâ't-Tevdîh, Daru'lFikr, ysz., tsz., I, 29vd.; 39vd. 
olmadığı anlaşılmaktadır. Onların zikrettikleri, harfin lafzî özellikleriyle sınırlıdır. Halbuki harfin hem lafzî hem de manevî özellikleri vardır. Bunun için harfin özelliklerinden bahsederken, öncelikle onları lafzî ve manevî olmak üzere ikiye ayırmak gerekir.

Harfin lafzî özellikleri denince, harfin telaffuzuyla veya kullanıldığı cümlede kendisinden kaynaklanan lafzî değişikliklerle ilgili özellikler kastedilmektedir.

\section{Harflerin Lafzî Özellikleri}

1- Harfin, isim ve fiilin alametlerinden hiçbirisini kabul etmemesi. Örneğin, hiçbir harfin başına لj takısı ve cer harfi gelmez. Il takısı veya cer harfinin gelmesi durumunda, onun harf olması mümkün değildir ${ }^{34}$

2- Harfin mebni olmasi. Yani bir harf cümlede hangi manaya gelirse gelsin, sürekli olarak sonu aynı şekilde kalmaktadır. Mebnilik, harfin temel bir özelliğidir. ${ }^{35}$

3- Kelime çeşidi olan harfin hece harflerinin sayısı beşi geçmemektedir. Bir kelimedeki harf beşten fazla ise, onun kelime çeşidi olan harfle bir ilgisinin olmadığı anlaşılır.

4- Harfin, müsned ve müsnedün ileyh olarak kullanılamaması. Harfin, bir cümlede müsnedün ileyh veya müsned olarak gelmemesinin nedeni, müsnedün ileyh ve müsned arasında hükmün var olmasından dolayıdır; çünkü hüküm bir nesne ve onunla ilgili bir özellikten bahsetmeyi gerektirmektedir. Harfin ifade ettiği hiçbir şeyde ise, nesne veya ona ait özellik yoktur. Iş̧te bundan dolayı nahivciler, harfin müsnedün ileyh ve müsnedün bih olamayacağını söylemişlerdir. ${ }^{36}$ Harfin bu özelliğinden dolayı da, onun cümlede esas öğe olmadığı söylenmiştir. Onun cümledeki yeri, değer olarak sürekli ikinci sırada gelmektedir. Onun bu özelliği, lüğat anlamıyla da ilgilidir; 37 çünkü daha önce geçtiği gibi lügatte harfin anlamlarından birisi de kenardır. Harfin cümlede ikinci derecede gelmesi gibi, bunu göstermektedir.

5- Bazı harflerin, kullanıldıkları cümlelerde, kelimelerin irablarını değiştirmeleri. Örneğin, : kendinden sonra gelen mübtedayı kendine isim yapıp harekesini fethiye veya onun yerine geçen bir alamete

34. İon Hişam, Evdahu' l-mesâlik, I, 13, 25

35. Abdurrahman b. Ahmed Molla Cami, el-Fevâidu'd-diyâiyye, s. 229; Mehmed Zihnî Efendi, el-Muktadab fin-nahiv, Marifet Yayınları, Istanbul 1991, s. 4.

36. Krş. Abdullah b. Salih, el-Muharrem Hâşiyetïl-Fevâidu'd-diyaiyye. Hurşit Matbaası, İstanbul 1318, I, 36; Abbas Hasan, en-Nahvu'l-Vafi, I,66.

37. el-Muradî, el-Cene'd-dânî, s. 24. 
çevirmektedir ${ }^{38}$ Harfler için söylediğimiz bu özellik, sadece bazı harfler için değil, aynı zamanda bazı isim ve fiiller için de geçerlidir.

6- Harflerin, nerede ve nasıl kullanılacaklarının belli olması. Harflerden bazıları sadece isimlerden önce; bazıları ise sadece fiillerden önce; bir kısmı da hem isimlerden hem de fiillerden önce gelmektedir. Örneğin, "il ve kardeşleri isim cümlelerinin; cer harfleri ise isimlerden önce kullanılırlar. $\mathrm{j} \mathrm{vb}$. harfler fiillere ait edatlardır.39 İsim ve fiillerin nerede ve nasıl kullanılacakları ise, nâdir olarak göruilen bir husustur.

7- Bazı harflerin, bazı kelimelerin sonuna gelmeleri ve o kelimelerin amel etmelerine engel olmalan. Örneğin, L harfi, ‘ v ve kardeşlerinin sonuna geldiğinde, nasp etmelerine; 20 vb. fiillerin sonlanna geldiğinde ise, ref etmelerine mani olmaktadır.

8- İsim ve fiilerin aksine harfin, tasrif edilememesi. Yani harfler isim ve fiiler gibi tesniye, cemi şeklinde çekilemezler. Bu, onların sürekli olarak hiçbir ek almadan aynı kalmalan demektir. İşte bundan dolayı harfler yapı itibariyle camittir.

\section{Harflerin Manevî Özellikleri}

Harflerin manevî özellikleri ise, onların cümle içindeki manalan ve fonksiyonlarıyla ilgilidir. Gördügümüz kadanyla nahiv kitaplarında bunlara çok az işaret edilmiştir.

1- Harflerin ifade ettikleri manalar geneldir. İsim ve fiillerin ifade

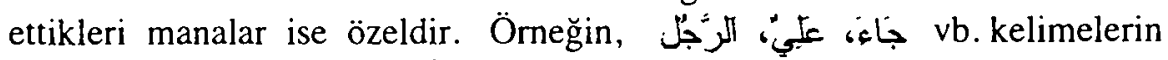
anlamları özeldir; çünkü جاء fiilinden "gelme olayının" geçmiş zamanda müfred müzekker bir şahıstan meydana gelmiş olduğu; الرجُجْر kelimesinin "söz konusu adam" veya "adam cinsi" ni ifade ettiği ve Ali isminin de özel bir şahsa delâlet ettiği anlaşılmaktadır. Görüldüğü gibi bu üç kelime de

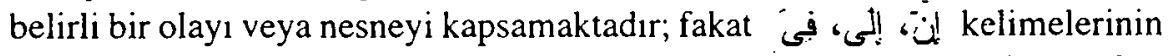
anlamı ise geneldir; zira bu kelimelerin taşıdıkları manalar, hemen hemen her varlık için söz konusu edilebilir. Örneğin, olumsuzluk, olumluluk, pekiştirme, zarfiyet, intiha(son) vb. manalar, kainatta birçok varlık için mümkündür; ama جاء fiilinin taşıdığı mana ise, yalnız canlı veya hareket etme kabiliyetine sahip olan şeyler için söz konusudur.

2- Harfler, cümlede bulundukları cümlenin durumuna göre, değişik anlamlara gelmektedir. Yani onların sürekli ve her yerde geçerli olan

38. İbn Hişam, a.g.e., I, 347; Muğni l-lebîb, el-Mektebetưl-Asriyye, Beyrut 1441/1991, I, 339.

39. el-Muradî, a.g.e. s. 25vd.; el-Galayinî, Camiu'd-Durusi l-Arabiyye, II, 298, III, 167.

40. el-Ğalayinî, a.g. e., I, 57 vd., II, 298, III, 167 
muayyen manaları yoktur. Fakat isim ve fiillerin manaları ise genelde muayyendir. Örneğin kelimelerinin manalan hiçbir zaman değişmez. Harflerin manalanındaki değişme özelliğinden dolayı, genelde onlardan herbirinin ne manaya geldiği âlimler arasında tartışma konusu olmuştur. Bazen onların manaları mübhem olarak kalmış; bazen de harfin bu özelliği nedeniyle cümlede kullanılan bir harf birden fazla

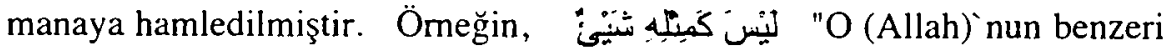
yoktur."4l ayetinde $s$ in manası hususunda değişik görüşler ileri sürüldüğünden dolayı, kesin bir şey söylemek mümkün değildir ${ }^{42}$ Örneğin

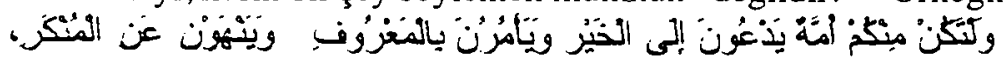
"Sizden insanlar hayra çağıracak, iyiliği emredecek ve kötülüğü nehyedecek bir topluluk bulunsun." ${ }^{33}$ ayetindeki, emrin farz-1 ayn mı farz-1 kifaye mi olduğu, Âlimlerin من مarfine verdikleri manadan anlaşılmaktadır. Eğer من in teb î̀ (bir kısım) için olduğu kabul edilirse, emir farz-1 kifâye; tebyîn veya tecrîd için olduğu kabul edilirse, emir farz-1 ayn olur. ${ }^{44}$ İşte görüldüğü gibi bu ayette مarfi iki manaya da hamledilebilecek bir özelliktedir.

3- Harf vasıtasıyla mana kısa ve öz bir şekilde, muhataba bildirilmektedir. Örneğin "adam evdedir." cümlesi harf olmadan ifade

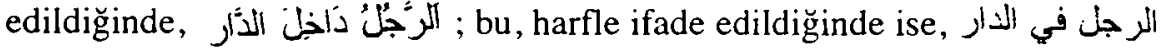

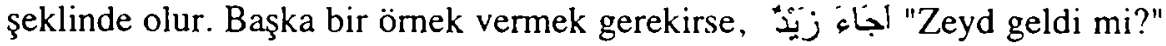
şeklindeki bir soruya veya $\forall$ harfleriyle cevap verilebilir. Her iki durumda da bir harf, bir cümlenin yerini almış olmaktadır; zira

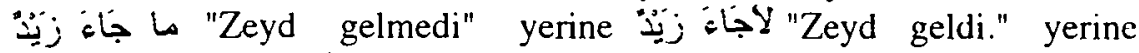
ise نعullanılabilir. İşte burada bu iki harf cümlenin yerini tutarak az bir sözle çok manayı ifade etmiş olur. ${ }^{45}$

4- Harfler cümlenin temel öğesi olarak kullanılmadıkları halde bazen cümlenin hem manasını hem de temel öğelerini değiştirmektedir. Örneğin, "Ali geldi ve Zeyd gitti." cümlesindeki Zeyd isminin başına ب harfi getirildiğinde, anlamı "Ali geldi ve Zeyd i götürdü." olur. İşte burada görüldüğui gibi ب harfiyle, hem cümlenin anlamı hem de temel

41. 42/eş-Şurâ, 11.

42. Zaid 'le ilgili geniş bilgi için bkz; Mahmûd b. Ömer ez-Zemahşeri, el-Keşsâf, Thk., Muhammed Abdusselam Şahîn, Daru'l-Kutubi' I-İlmiyyc, Beyrut 1415/1995, IV, 207vd; Fahreddin er-Râzî, Mefâtîhu'l-ğayb, Daru’l-Fikr, Beyrut 1415/1995, XIV, 27. cüz., 153vd. ve Mahmûd b. Yusûf Ebû Hayyân, el-Bahru'l-muhît, Daru'l-Fikr, Beyrut, 14I21992, IX, 326.

43. 3/Al-i İmran, 104.

44. Fahreddîn er-Râzî, a. g.e., IV, 8. cüz, 182vd.; Elmalı Hamdî Yazır, Hak Dini Kur ân Dili, Eser Neşriyat, İstanbul 1971, II, 1155.

45. İbn Hişam, Evdahu'l-mesalik, I, 398; Emîl Bedî’, a.g.e., s. 9 
öğesi değişmiştir; çünkü daha önce Zeyd kelimesi fâil konumundayken, mefûl konumuna geçmiş ve gizli 'ُ zamiri de fâil olup Ali ye dönmüştür. ${ }^{46}$

5- Harflerin zâid olarak kullanılmaları yaygındır; fakat isim ve fiillerin zaid olarak kullanılmalan ise nâdirdir. Zâid harfler kullanıldıklan cümlenin

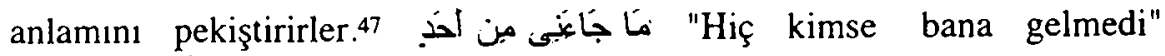
örneğinde من مarfi zâiddir ve cümlenin manasını pekiştirmektedir.

6- Bazı harfler, sonlarına bitiştikleri kelimelerin anlamını ya değiştirirler ya da pekiştirirler. Örneğin, "ن] “in sonuna gelen L harfi, onun manasını tahsîse çevirmekte; şart isimlerinin sonuna gelen $L_{s}$ ise, onların manalarını pekiştirmektedir ${ }^{48}$

7- Harfler, varlıkların ve özelliklerinin kendisini değil de, ikisi arasındaki bağlantıyı ifade ettiklerinden dolayı, kelime türleri arasında sayıca en az olanlarıdır; zira varlıklar ve özellikleri arasındaki bağlantılar genelde ya aynı veya bibirinin benzeri olurlar. Ömeğin, olumsuzluk anlamı her varlık ve özellik için söz konusu olabilir ve nesne veya özelliklerdeki bu olumsuzluğu anlatırken kullanılan ifadeler ya aynı ya da birbirlerine yakın olur. Halit hasta değil, Mahmut çalışkan değil vb. cümleleri dizdiğimizde, hepsinde olumsuzluk edatı olarak "değil"i kullanacağız. İşe birçok cümlede aynı harfler kullanıldığından dolayıdır ki, harf, kelime çeşitleri arasında en az olan kelime türüdür. Kısacası olayların çoğalmasıyla, olaylar arasındaki bağlantı yönünü ifade eden lafızlar çoğalmamış, sadece olaylar değişik kategorilere taksim edilmiştir. Bu da zarfiyet, nefî, te’kîd vb. kategoriler şeklinde olmuştur. Bazı âlimler, harflerin sayıca az olmasını gerekçe göstererek onların herhangi bir tanıma ihtiyaçlarının olmadığını söyleyenlerin olduğunu belirtmişlerdir. ${ }^{49}$

8- Harflerin esas görevi, manalar arasındaki ilişkiyi kurmaktır. Harfin bir tarifinde geçtiği gibi harf, genellikle bağlaç görevini görmektedir. Bu, harf olmadan çoğu zaman insanın meramını ifade edememesine ve onların dilde en fazla kullanılmasına yol açmıştır; zira yukarıda söylediğimiz gibi onların önemli bir özellikleri de bağlaç görevini yapmalarıdır. Bu ister istemez harflerin daha fazla kullanılmalarını sağlamıştır.

9- Harfler, dildeki esnekliğe en uygun olan kelime türüdür. Daha önce söylediğimiz gibi, bir harf bir cümlede değişik anlamlara gelebilmektedir. Bu

46. Abdullah b. Hüseyin el-Ukberî, el-Lubâb fí 'ileli l-bina ve`l-i râb, Daru`l-Fikr, Dımaşk 1416/1995, s. 270; et-Taftazanî Saduddin, Şerhu`s-Sad ala Tasrif-i Zencanî, tsz, Ysz, II, 38.

47. es-Suyûtî, Behcetül-mardiyye, s. 116;.el-Ğalayini, a.g.e, III,186.

48. et-Teftâzânî, el-Mutavvel, s. 210; Ibn Akîl, a.g.e., II, 339

49. İbnu's-Serrâc, a.g.e., II, 206; el-Murâdî, a.g.e., s. 20. 
da hem mananın hem de irabın değişmesine sebep olmakta ve dile esneklik kazandırmaktadır. Örneğin, يسن الثه cümlesindeki بـülâbese ve isti âne

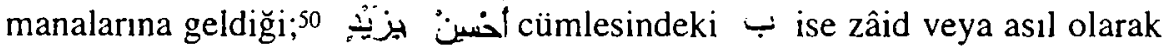
geldiği hususunda ihtilaf olmuştur. Zâid diyenlere göre, fail, $ب$ harfinin başına geldiği Zeyd kelimesi olmakta; asıldır diyenlere göre de fâil, gizli olması vacip olan o zamiri olmaktadır.51

11- Harfler, kelimelerin tür değiştirmesine sebep olmaktadır. Örneğin, "il i mastariyye müzari olan fiilin başına geldiğinde onu isimleştirir. ${ }^{52}$

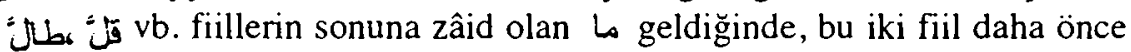
mutasanf iken câmid olurlar. ${ }^{53}$ Yine ${ }^{3}$ isim ve haberinin anlamını mastara çevirmektedir. ${ }^{54}$

12- Harflerde zamirin gizli olduğu söz konusu edilemez. Ancak fiil ve müştak isimlerde gizli bir zamirin mevcut olması mümkündür.

13- Harfler için hakiki anlamda müzekker ve müenneslik yoktur. Arapça metinlerde harflere dönen müennes veya müzekker zamirleri, mecâzî anlamdaki müenneslik ve müzekkerliği ifade etmektedir.

Sonuç, nahiv âlimleri arasında yaygın olarak harf için tanım olarak

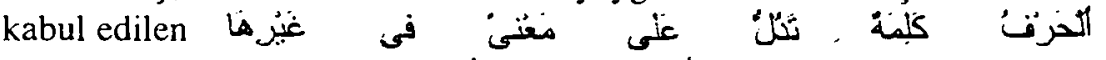

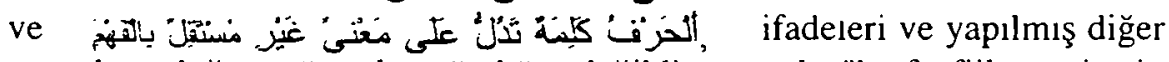
tanımları doğru görmek mümkün değildir; ancak "harf, fiil ve ismin özelliklerini kabul etmeyen kelimedir." şeklindeki bazı âlimlerin tanımları bundan müstesnadır; zira onların bu tanımları harf için efradı câmi ve ağyarı manidir. Harfin özelliklerine gelince, nahiv kitaplarında genelde harfin lafzî özelliklerinin bir kısmından bahsedilmiştir. Manevî ve bir kısım lafzî özelliklerine ise ya çok az ya da hiç değinilmemiştir.

50. Ahmed Şihâbuddîn el-Hafacî, Inâyetï l-kadî ve kifâyetï r-râdî, Daru Kutubii'l-İlmiyye, Beyrut 1417/1998, 1,60; Molla Yunus el-Erkutnî, Kitabu’t-terkîb, s. 2; Mustaf el-Hisnu’ lMensûrî, el-Muktataf min uyûni' '-tefasir, Thk. M. Ali es-Sâbûnî, Dan' I-Kalem, Dımaşk, 1416/1996, I, 9.

51. cz-Zemahşerî, el-Mufassal, s. 330; el-Galâyînî, a.g.e., I, 68vd.

52. Molla Câmî, a.g.e., s. 344 .

53. el-Galâyînî, a.g.e., I, 57vd.

54. es-Suyûtî, Hem 'u'l-Hevâmi', I, 137. 